\title{
The Kelp Gull as bioindicator of environmental chemicals in the Magellan region. A comparison with other coastal sites in Chile*
}

\author{
JACQUELINE MUÑOZ1 and PETER H. BECKER ${ }^{2}$ \\ ${ }^{1}$ Instituto de Zoología, Universidad Austral de Chile, Valdivia, Chile \\ ${ }^{2}$ Institut für Vogelforschung "Vogelwarte Helgoland", D-26386 Wilhelmshaven, Germany
}

\begin{abstract}
SUMMARY: During the breeding seasons 1994/5 and 1995/6 we collected Kelp Gull (Larus dominicanus) eggs from five locations in central to south Chile to study the contamination with mercury and organochlorine compounds. The sites were Algarrobo, Concepción, Maiquillahue Bay, Doña Sebastiana Island (Chalcao channel at Chiloé) and Magdalena Island (Straits of Magellan). We found differences among the sites: Kelp Gull eggs from Chiloé and Algarrobo had the greatest concentrations of mercury (about $170 \mathrm{ng} \mathrm{g}^{-1}$ fresh weight). Residues of DDT were greatest in eggs from Algarrobo and Maiquillahue Bay, those of PCBs (polychlorinated biphenyls) greatest at Algarrobo and Concepción. HCB had highest levels at Concepción. Considering all organochlorines, samples from Algarrobo had the highest concentrations, those from Chiloé the lowest. In consequence we found a geographical pattern from north to south, i.e., from areas with greater to lesser human impact. In comparison with other studies, the levels of environmental chemicals found in Kelp Gulls from Chile are much lower than those known to cause adverse effects on reproductive success.
\end{abstract}

Key words: Environmental chemicals, Kelp Gull, Larus dominicanus, eggs, Chile, mercury, organochlorines, PCBs

RESUMEN: LA GAVIOTA DOMINICANA COMO BIOINDICADOR DE LOS PRODUCTOS QUÍMICOS AMBIENTALES EN LA REGIÓN DE MAgallanes. UnA COMPARACIÓN CON OTRAS lOCALIDADES COSTERAS EN ChILE. - Durante las estaciones reproductoras de los años 1994/5 y 1995/6 recolectamos huevos de la gaviota dominicana (Larus dominicanus) en cinco localidades ubicadas entre el centro y sur de Chile para el estudio de la contaminación por mercurio y compuestos organohalogenados. Dichas localidades fueron Algarrobo, Concepción, Bahía de Maiquillahue, Isla Doña Sebastiana (Canal de Chacao-Chiloé) e Isla Magdalena (Estrecho de Magallanes). Los huevos de la gaviota dominicana provenientes de la Isla Doña Sebastiana y Algarrobo presentaron las mayores concentraciones de mercurio (170 $\mathrm{ng} \mathrm{g}^{-1}$ peso fresco). Los mayores niveles de residuos de DDT fueron detectados en las muestras procedentes de Algarrobo y de Bahía de Maiquillahue, los mayores niveles de residuos de PCBs (bifenilos policlorinados) en las muestras de Algarrobo y de Concepcíon. Los mayores valores de HCB se hallaron en Concepción. Considerando la suma de todos los compuestos organoclorados, los huevos provenientes de Algarrobo presentaron las mayores concentraciones y los de la Isla Doña Sebastiana las menores. En consecuencia, se encuentra un patrón de variación geográfica de norte a sur y de mayor a menor impacto. En comparación con otros estudios, los niveles de los productos químicos ambientales encontrados en los huevos de gaviota dominicana en Chile pueden considerarse muy bajos como para provocar efectos adversos sobre el éxito reproductor.

Palabras clave: Productos químicos ambientales, Larus dominicanus, huevos, Chile, mercurio, organoclorados, PCB

*Accepted July 14, 1998. 


\section{INTRODUCTION}

Coastal ecosystems are often very vulnerable and exposed because of their proximity to pollution sources, such as industrial emissions, municipal discharges containing chemical products, and biocides used in agriculture. The pollutants are transported by the rivers and /or atmosphere or are directly discharged into the sea. In aquatic environments, many chemicals are accumulated by organisms and biomagnified via the food chains to high levels in the tissues of top-predators like fish-eating birds. Persistent organochlorines are very lipophilic, and during the breeding season they are mobilized and deposited into the eggs bound to the yolk-fat (e.g. Furness, 1993, Henriksen et al., 1996). In this way, the eggs of seabirds can be used as bioindicators of contamination in coastal and marine environments (e.g. Nisbet and Reynolds, 1984; Becker, 1989, 1991; Becker et al., 1992; Tillitt et al., 1992; Furness, 1993). The Kelp Gull (Larus dominicanus, Lichtenstein 1823) has a wide distribution and eats a wide variety of food (Hoyo et al., 1996); hence the eggs of this species may be good indicators of the chemical pollution of the environment (like eggs of Herring Gulls Larus argentatus, Pontoppidan 1763: Weseloh et al., 1990).

As in other countries, in Chile mercury and organochlorine compounds have been used in industry and agriculture, but the knowledge of Chilean marine pollution is poor. Recently, Focardi et al. (1996) analysed organochlorine residues in fish and birds at the Biobio river; the animals contained high concentrations of PCBs at the river's mouth. Although some environmental chemicals are prohibited in Chile since 1981 (e.g. historical pesticides like DDT, Aldrin, Endrin, Dieldrin), we expect them still to exist in the environment owing to their persistence. But nowadays also a large number of various insecticides, fungicides and herbicides are in use in Chile (Barra et al., 1995).

The objective of this study is to determine spatial trends in contamination of Kelp Gulls along the Chilean coast, from areas with varying human

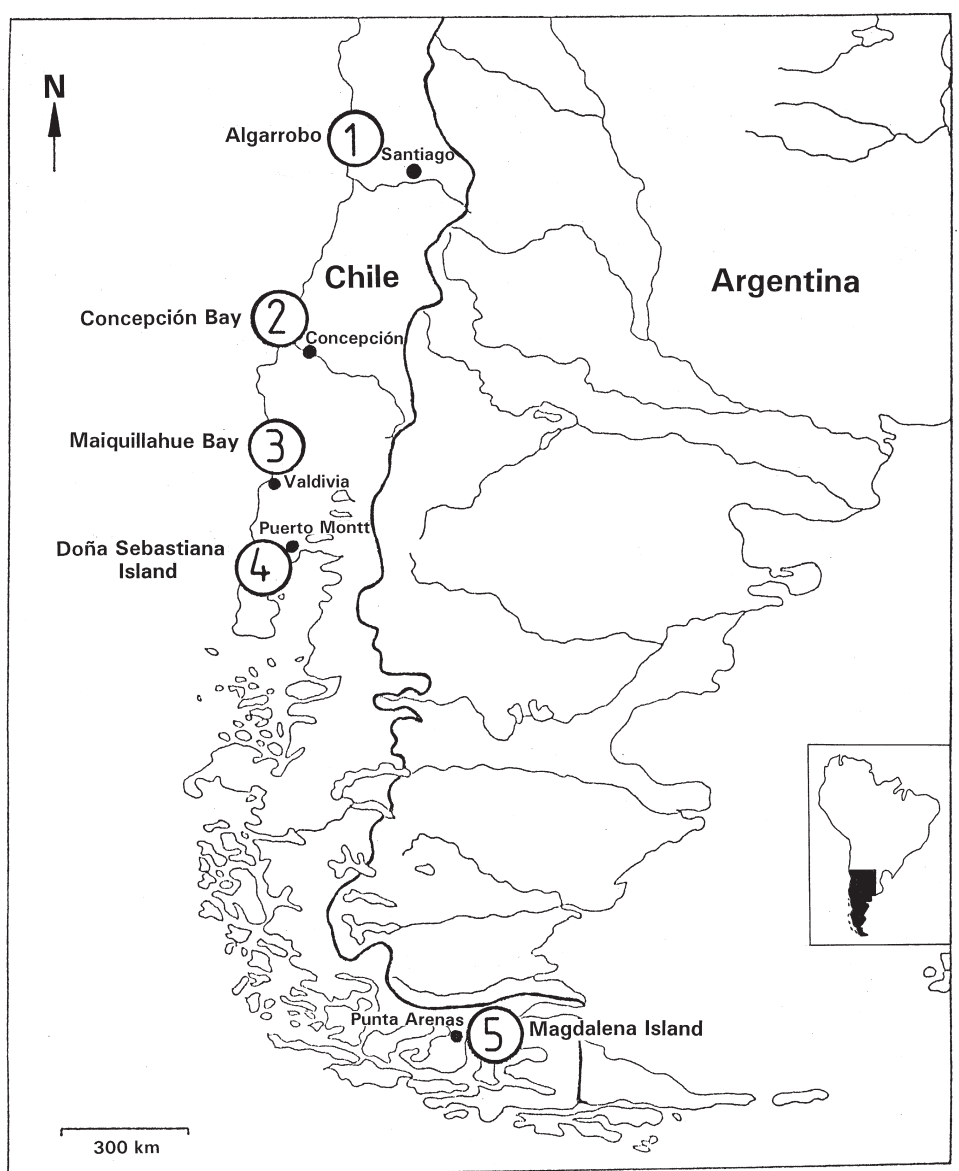

FIG. 1. - Sampling sites for Kelp Gull eggs in Chile. 1: Algarrobo, 2: Concepción, 3: Maiquillahue Bay, 4: Doña Sebastiana Island (Chacao channel at Chiloé, and 5: Magdalena Island (Strait of Magellan). Eggs were taken in the breeding seasons 1994/5 or 1995/6. 
impact. We analyze mercury and organochlorinated compounds in eggs collected in the Magellan region for comparison with that of other sites in Chile, to evaluate the pollution of the Magellan area.

\section{MATERIAL AND METHODS}

During the breeding seasons 1994/5 and 1995/6 samples of Kelp Gull eggs ( $n=7-20)$ were collected from each of five sites along the Chilean coast. The sites (Fig. 1) and sampling dates were Algarrobo

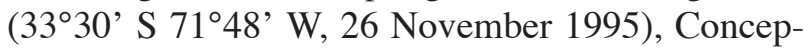
ción (Faro Hualpen $36^{\circ} 40^{\prime}$ S $73^{\circ} 26^{\prime}$ W, 11 January 1995 , Isla Quiriquina $36^{\circ} 37^{\prime} \mathrm{S} 73^{\circ} 03^{\prime} \mathrm{W}, 10$ December 1995), Maiquillahue Bay (39³0' S 73³6' W, 19 November - 17 December 1995), Doña Sebastiana Island (Chacao channel at Chiloé,

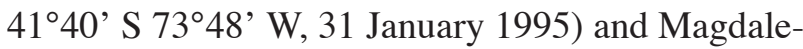
na Island (Straits of Magellan, $53^{\circ} 05^{\prime} \mathrm{S} 71^{\circ} 00^{\prime} \mathrm{W}$, December 1995, Fig. 1).

One egg per completed clutch was taken at random (see Table 1 for $\mathrm{n}$ ). The eggs were stored frozen $\left(-18^{\circ} \mathrm{C}\right)$. Some eggs contained embryos (max two weeks old). As we found no significant correlation of egg weight and embryo age $\left(\mathrm{r}_{\mathrm{s}}-0.096, \mathrm{n}=39\right)$ and as egg mass loss should only be up to $6.7 \%$ during the first two weeks of incubation (Herring Gull, Drent, 1970), we analysed each homogenized egg individually on fresh weight basis.

For determination of organochlorine compounds $2 \mathrm{~g}$ of the egg homogenate were dried with sodium sulfate, cleaned by a column filled with silica gel, eluted with n-hexane:dichloromethane (8:2), evaporated and taken up in $250 \mathrm{Bl}$ toluen. A gas chromatograph HP 5890, series II, coupled with a mass selective detector HP 5971 was used, with electron impact ionization and measure in SIM-mode. Two HT-5- columns with an overall length of $50 \mathrm{~m}$ were utilized for the separation. See Sommer et al. (1997) for details and for the quantification of pesticides and CB congeners. For mercury determination $100 \mathrm{mg}$ egg homogenate were prepared with a mixture of nitric acid, chloric acid and perchloric acid in partly closed test tube. An atomic absorption spectrometer (FIMS400, Perkin Elmer) with an integrated flow injection module of the FIAS series was used for the measurement. Detection limits were $0.1 \mathrm{ng} \mathrm{g}^{-1}$ fresh egg for mercury, and $0.3-0.9 \mathrm{ng} \mathrm{g}^{-1}$ for all examined organochlorines. Concentrations are given in $\mathrm{ng} \mathrm{g}^{-1}$ egg fresh weight.
The organochlorine compounds analyzed were hexachlorobenzene (HCB), three isomers of hexachlorocyclohexane $(\alpha-, \beta-$ and $\gamma-\mathrm{HCH})$ and also their sum $(\mathrm{SHCH})$, DDT (expressed as SDDT including six metabolites: op'-DDT, op'-DDE, op'DDD, pp'-DDT, pp'-DDE, pp'-DDD), and polychlorinated biphenyls (PCBs). We analyzed 62 congeners of PCBs (expressed as the sum, SPCB), 41 of them were recorded individually. For comparison with other studies we also calculated the sum of six "indicator congeners" (PCB6CONG; Bundesminister für Umwelt, 1988; referred to by the IUPACnumbers, Ballschmiter and Zell, 1980), PCB 28, PCB 52, PCB 101, PCB 138, PCB 153 and PCB 180. Moreover toxic $\mathrm{PCB}$ congeners were grouped to non- (PCB 126, PCB 169), mono- (PCB 105, PCB114, PCB 118, PCB 123, PCB 156, PCB 157, PCB 167, PCB 189), and di-ortho congeners (PCB 128, PCB 138, PCB 158/129, PCB 196, PCB 170; Safe et al., 1985). As the toxicity depends on both the quantity and position of the chlorine-atoms, we considered also the degree of chlorination $(\mathrm{PCB} 3 \mathrm{Cl}$ to $\mathrm{PCB} 8 \mathrm{Cl}$, Table 2). Concentrations of all organochlorines were summed up per egg as total organochlorine concentration (SORGANOCHLORINE).

SPSS/PC+ was used for statistical analyses. For statistical comparisons among sites, means were compared by analysis of variance. The data were $\log$-transformed $(\log x+1)$ prior to analyses. Statistical significance of differences was determined using Scheffé-tests and $\mathrm{p}<0.05$ chosen as significance level.

\section{RESULTS}

In most chemicals analyzed we found significant spatial variation (Fig. 2, Table 1, 2).

The samples from Algarrobo site (5) and Doña Sebastiana Island (4) had the highest levels of the heavy metal mercury (Fig. 2, Table 1), those from Concepción (2) the lowest.

The concentrations of DDT and metabolites were significantly higher at Algarrobo (1) and Maiquillahue Bay (3) than at the other sites (Fig. 2, Table 1). In all locations, without exception, pp'-DDE was the most concentrated metabolite (pp'-DDE/SDDT ratio upper 0.9); the op' -metabolites of DDE, DDD and DDT were not detected. The concentrations of pp'-DDT and of SHCH were very low and not significantly different between sites (Table 1, Fig. 2). 

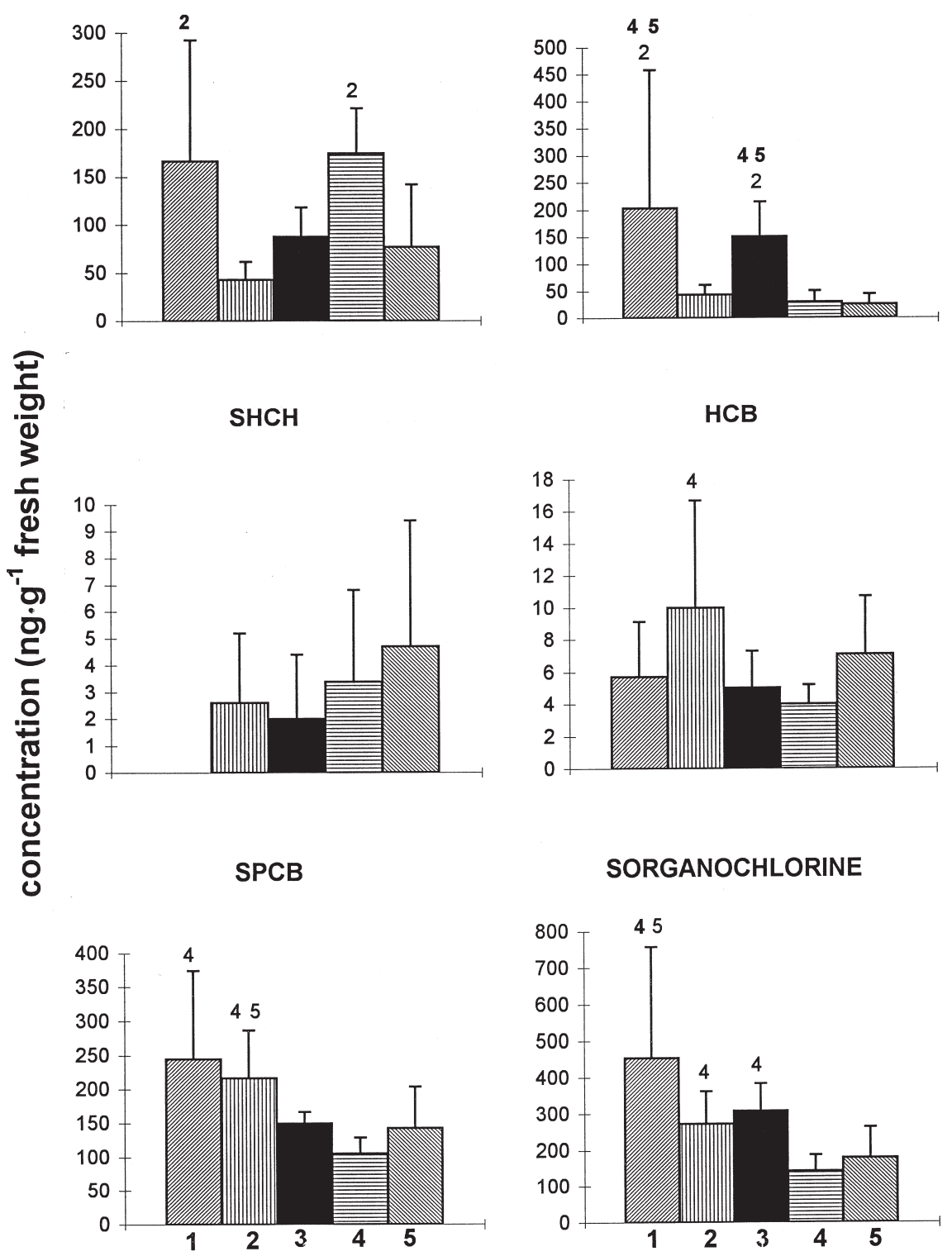

site

FIG. 2. - Concentrations of environmental chemicals in Kelp Gull eggs from 5 locations on the Chilean coast (see Fig. 1). 1: Algarrobo, 2: Concepción, 3: Maiquillahue Bay, 4: Doña Sebastiana Island (Chacao channel at Chiloé), and 5: Magdalena Island (Strait of Magellan). Concentration of all organochlorines investigated: SORGANOCHLORINE. Means $+1 \mathrm{~s}$. Significant intersite differences are indicated by the site number at the top of the column with the significant higher value $(\mathrm{p}<0.05$; bold numbers $\mathrm{p}<0.001)$.

$\alpha-\mathrm{HCH}$ was not detected in any eggs, $\beta-\mathrm{HCH}$ occurred only at Concepción (2) and Magdalena Island (site 5; Table 1). Only in eggs from the Magellan region, was the concentration of $\mathrm{\beta}-\mathrm{HCH}$ higher than that of $\gamma-\mathrm{HCH}$. The concentrations of HCB were greatest in eggs from Concepción (2), but significantly different only between Concepción and Doña Sebastiana Island (site 4; Table 1, Fig. 2).

The levels of PCBs are shown in Fig. 2 and Table 2. The samples from Algarrobo (1) showed higher concentrations of SPCB and of the six "indicator congeners" (PCB6CONG), but the intersite differences were significant only compared to the eggs from Doña Sebastiana Island (4) or to Magdalena Island (5). The non-ortho congeners were not detected in any samples. Also the mono- and di-ortho congeners had highest levels at Algarrobo (1) and Concepción (2). The PCBs with three, four and five chlorine-atoms showed no differences among sites (Table 2). In general, the PCBs with six, seven and 
TABLE 1. - Levels of mercury and organochlorines in eggs of Kelp Gulls from five locations in Chile in ng $\mathrm{g}^{-1}$ fresh weight (means \pm sd). See Table 2 for PCBs. $\alpha-H C H$, op'-DDD, op'-DDE, op'-DDT were not detected. Significant intersite differences are indicated by the location numbers (at least $\mathrm{p} \leq 0.05$ ).

\begin{tabular}{|c|c|c|c|c|c|}
\hline & $\begin{array}{c}1 \\
\text { Algarrobo } \\
(n=10)\end{array}$ & $\begin{array}{c}2 \\
\text { Concepción } \\
(n=20)\end{array}$ & $\begin{array}{c}3 \\
\text { Maiquillahue } \\
\text { Bay }(n=7)\end{array}$ & $\begin{array}{c}4 \\
\text { Doña Sebastiana } \\
\text { Island }(n=8)\end{array}$ & $\begin{array}{c}5 \\
\text { Magdalena } \\
\text { Island }(n=10)\end{array}$ \\
\hline mercury & $166.7 \pm 125.7^{2}$ & $43.5 \pm 18.3^{1,4}$ & $88.0 \pm 30.8$ & $175.0 \pm 46.2^{2}$ & $77.0 \pm 65.3$ \\
\hline $\mathrm{HCB}$ & $5.7 \pm 3.4$ & $9.9 \pm 6.7^{4}$ & $5.0 \pm 2.3$ & $4.0 \pm 1.2^{2}$ & $7.1 \pm 3.6$ \\
\hline$\beta-\mathrm{HCH}$ & 0.0 & $0.6 \pm 1.8$ & 0.0 & 0.0 & $2.7 \pm 3.1$ \\
\hline$\gamma-\mathrm{HCH}$ & $0.0^{4}$ & $2.0 \pm 2.3$ & $2.0 \pm 2.4$ & $3.4 \pm 2.1^{1}$ & $2.0 \pm 2.1$ \\
\hline $\mathrm{SHCH}$ & $0.0^{5}$ & $2.6 \pm 3.6^{5}$ & $2.0 \pm 2.4^{5}$ & $3.4 \pm 2.1^{5}$ & $4.7 \pm 5.1^{1-4}$ \\
\hline pp'-DDD & $5.8 \pm 5.0^{5}$ & $2.3 \pm 3.6$ & $5.5 \pm 3.3^{5}$ & $1.6 \pm 3.0$ & $0.0^{1,3}$ \\
\hline pp'-DDE & $191.9 \pm 243.8^{2,4,5}$ & $40.2 \pm 17.0^{1,3}$ & $138.8 \pm 57.2^{2,4,5}$ & $28.0 \pm 20.2^{1,3}$ & $23.8 \pm 19.0^{1,3}$ \\
\hline pp'-DDT & $5.3 \pm 8.7$ & $0.6 \pm 2.8$ & $6.8 \pm 8.8$ & 0.0 & $1.3 \pm 4.1$ \\
\hline SDDT & $203.0 \pm 255.2^{2,4,5}$ & $43.2 \pm 18.7^{1,3}$ & $151.0 \pm 63.9^{2,4,5}$ & $29.6 \pm 21.6^{1,3}$ & $25.1 \pm 19.2^{1,3}$ \\
\hline SORGANOCHLOR & $454.0 \pm 304.2^{4,5}$ & $272.8 \pm 88.8^{4}$ & $307.9 \pm 75.6^{4}$ & $142.7 \pm 44.4^{1-3}$ & $179.5 \pm 83.3^{1}$ \\
\hline
\end{tabular}

TABLE 2. - Levels of PCBs in eggs of Kelp Gulls from five locations in Chile in $\mathrm{ng} \cdot \mathrm{g}^{-1}$ fresh weight (means $\pm \mathrm{sd}$ ). Non-ortho PCBs were not detected. See text for details. Significant intersite differences are indicated by the location numbers (at least $\mathrm{p} \leq 0.05$ ).

\begin{tabular}{|c|c|c|c|c|c|}
\hline & $\begin{array}{c}1 \\
\text { Algarrobo } \\
(\mathrm{n}=10)\end{array}$ & $\begin{array}{c}2 \\
\text { Concepción } \\
(\mathrm{n}=20)\end{array}$ & $\begin{array}{c}3 \\
\text { Maiquillahue } \\
\text { Bay }(n=7)\end{array}$ & $\begin{array}{c}4 \\
\text { Doña Sebastiana } \\
\text { Island }(n=8)\end{array}$ & $\begin{array}{c}5 \\
\text { Magdalena } \\
\text { Island }(n=10)\end{array}$ \\
\hline PCB28 & $4.1 \pm 2.7$ & $3.5 \pm 0.7$ & $3.5 \pm 0.3$ & $3.0 \pm 0.2$ & $2.8 \pm 0.4$ \\
\hline PCB52 & $3.5 \pm 1.4$ & $3.5 \pm 0.7$ & $4.1 \pm 0.8$ & $3.4 \pm 0.4$ & $2.8 \pm 0.3$ \\
\hline PCB101 & $6.6 \pm 2.1$ & $6.3 \pm 1.9$ & $7.8 \pm 1.8$ & $5.4 \pm 0.9$ & $6.7 \pm 1.5$ \\
\hline PCB118 & $9.8 \pm 5.7^{4,5}$ & $9.2 \pm 3.6^{3-5}$ & $4.9 \pm 0.9^{2}$ & $4.5 \pm 0.9^{1,2}$ & $4.9 \pm 2.2^{1,2}$ \\
\hline PCB138 & $17.1 \pm 11.9^{4}$ & $14.4 \pm 6.0^{3-5}$ & $7.2 \pm 1.0^{2}$ & $5.2 \pm 2.0^{1,2}$ & $8.5 \pm 4.6^{2}$ \\
\hline PCB153 & $35.8 \pm 24.0^{3-5}$ & $27.6 \pm 11.8^{3,4}$ & $13.4 \pm 2.4^{1}$ & $9.5 \pm 4.4^{1,2}$ & $17.2 \pm 10.7^{1}$ \\
\hline PCB180 & $20.2 \pm 17.9^{4,5}$ & $16.3 \pm 6.9^{3,4}$ & $7.0 \pm 1.3^{2}$ & $5.0 \pm 2.0^{1,2}$ & $11.0 \pm 9.6$ \\
\hline PCB6CONG & $87.3 \pm 56.4^{4}$ & $71.6 \pm 25.4^{4}$ & $43.1 \pm 6.1$ & $31.4 \pm 9.6^{1,2}$ & $49.0 \pm 24.7$ \\
\hline MONORTHO & $23.6 \pm 14.2^{5}$ & $19.7 \pm 8.8^{5}$ & $13.3 \pm 4$ & $9.7 \pm 2.2$ & $9.0 \pm 4.1^{1,2}$ \\
\hline DIORTHO & $30.3 \pm 20.6^{4}$ & $26.1 \pm 9.9^{2,4}$ & $15.4 \pm 2.5$ & $9.7 \pm 4.3^{1,2}$ & $15.7 \pm 7.9^{2}$ \\
\hline $\mathrm{PCB} 3 \mathrm{Cl}$ & $4.1 \pm 2.7$ & $3.5 \pm 0.7$ & $3.5 \pm 0.3$ & $3.0 \pm 0.2$ & $2.8 \pm 0.4$ \\
\hline PCB4Cl & $22.5 \pm 8.5$ & $21.7 \pm 3.9$ & $21.2 \pm 1.3$ & $19.9 \pm 1.3$ & $17.0 \pm 1.7$ \\
\hline PCB5Cl & $50.0 \pm 21.1$ & $47.3 \pm 12.4$ & $44.2 \pm 3.5$ & $34.9 \pm 4.4$ & $34.8 \pm 6.5$ \\
\hline PCB6Cl & $90.2 \pm 52.2^{4,5}$ & $74.2 \pm 28.7^{4}$ & $47.1 \pm 5.3$ & $31.0 \pm 11.4^{1,2}$ & $47.5 \pm 22.1^{1}$ \\
\hline $\mathrm{PCB} 7 \mathrm{Cl}$ & $64.1 \pm 44^{4,5}$ & $54.3 \pm 21^{4}$ & $30.6 \pm 8.4$ & $16.9 \pm 6.3^{1,2}$ & $32.8 \pm 23^{1}$ \\
\hline $\mathrm{PCB} 8 \mathrm{Cl}$ & $14.1 \pm 11.9^{4}$ & $15.9 \pm 6.9^{3-5}$ & $2.9 \pm 3.2^{2}$ & $0.0^{1,2}$ & $7.6 \pm 12.9^{2}$ \\
\hline SPCB & $245.2 \pm 128.9^{4}$ & $216.8 \pm 70^{4,5}$ & $149.8 \pm 16.9$ & $105.7 \pm 23^{1,2}$ & $142.5 \pm 61.1^{2}$ \\
\hline
\end{tabular}

eight chlorine-atoms had highest concentrations at Algarrobo (1) and Concepción (2). The same trend was found in single PCB congeners (Table 2).

The total concentration of all organochlorine compounds (Fig. 2, Table 2) was greater in samples from Algarrobo (1), although only significantly different from those from Doña Sebastiana Island (4) and Strait of Magellan (5) $(\mathrm{p}<0.05)$.

\section{DISCUSSION}

The existence of geographical patterns in the contamination of Kelp Gulls along the Chilean coast was confirmed for most chemical compounds, e.g. mercury, the higher chlorinated PCBs, and SDDT. Mercury occurred in highest concentrations in eggs from Algarrobo and the Doña Sebastiana Island, where industrial activities are very low. Volcanic mercury input may be a possible pollution source in this area.

Among the pesticides, levels of DDT and metabolites were significantly higher in Algarrobo and Maiquillahue Bay in comparison with the other sites. This pattern may be caused by the highly developed agriculture in these regions (Algarrobo, region V: cultivation of fruits, vegetables; Maiquillahue Bay, region IX/X: grain- and corn-growing). The consumption of agrochemicals in region $\mathrm{V}$ and IX of Chile was much higher than in the VIII (Concepción) and X (Doña Sebastiana Island, Barra et al., 1995), probably also during the 1970s, when DDT was still in use. The residues of pp"-DDT found in eggs of Kelp Gulls in 1994/5, however, 
indicate a more recent application of DDT in both areas. SHCH and HCB had very low concentrations and did not show clear geographical variation. Nevertheless, the highest concentrations of lindane $(\gamma-$ $\mathrm{HCH}$ ) were found in eggs from Doña Sebastiana Island (region $\mathrm{X}$ ), where lindane is more in use than in the other regions of Chile (Barra et al., 1995).

Also the industrial PCBs showed a geographical trend, characterized by highest concentrations at Algarrobo (adjacent to the harbour of Valparaíso) and Concepción (industrial area); both areas are zones of major anthropogenic pollution. This decreasing trend from north to south in gull contamination with PCBs, and also with the organochlorine total, corresponds to a decrease in density of the human population from central Chile to the Magellanic area (region V, Allgarrobo (1), Fig. 1: 84 inhabitants $/ \mathrm{km}^{2}$; region VIII, Concepción (2): 47 inhabitants $/ \mathrm{km}^{2}$; Maiquillahue Bay (3): between region IX, 25 inhabitants $/ \mathrm{km}^{2}$, and region $\mathrm{X}, 14$ inhabitants $/ \mathrm{km}^{2}$, Doña Sebastiana Island, Chacao channel at Chiloé (4): region $\mathrm{X}$ (see above); region XII, Magdalena Island (5): 1 inhabitant $/ \mathrm{km}^{2}$; Seeler 1994) and reflects the use or emission of these xenobiotics in the urban and industrial areas (see also Focardi et al., 1996). According to Focardi et al. (1996), most PCB residues in fish and birds near Concepción consisted of congeners between penta- and heptachlorobiphenyls, which also showed significant spatial variation (Table 2).

That means that the relatively important oil and gas industry in the Magellan region (Punta Arenas) did not cause serious pollution problems by industrial chemicals for the seabirds (PCBs, mercury). But the pesticide levels in the eggs from that area were also low in comparison with northern sites of the Chilean coast. The Magellan area is characterized by extensive stock farming with the consequence of minimal pollution by pesticides. These compounds originate from the intensive agriculture and forestry concentrated in the central region of Chile and producing higher contamination of the environment, including seabirds.

Intersite differences in diet composition may be another source of variation in contaminant loads of the gulls. For example, benthic organisms are less contaminated by organochlorines than fish (e.g. Mattig et al., 1997). In consequence, higher proportions of fish in the diet would lead to larger amounts of residues in the gulls. Food composition, however, was not investigated.
TABLE 3. - Comparison of egg contamination (ng/g, arithmetic means) of Kelp Gulls in Chile and Herring Gulls in North America (Weseloh pers. comm.) and Europa (Muñoz and Becker unpubl. data) in 1995

\begin{tabular}{lcrr}
\hline & $\begin{array}{c}\text { Kelp Gull } \\
\text { Larus dominicanus } \\
\text { Algarrobo }\end{array}$ & \multicolumn{2}{c}{$\begin{array}{c}\text { Herring Gull } \\
\text { L. argentatus }\end{array}$} \\
& & Lake Ontario & German Wadden Sea \\
\hline $\mathrm{n}$ & 9 & 1 pooled sample & 12 \\
pp'-DDE & 192 & 2590 & 62 \\
$\beta$-HCH & 0 & 0 & 5 \\
HCB & 6 & 22 & 11 \\
SPCB & 245 & 14800 & 1623 \\
Hg & 167 & - & 163 \\
\hline
\end{tabular}

The Herring Gull is closely related to the Kelp Gull and very similar in feeding and reproductive ecology. In North America and Europe Herring Gulls have been widely used as bioindicator for chemical contamination of aquatic environments. Several studies have shown that the concentration of pollutants in their eggs reflect the female's contaminant load (Becker et al., 1989; Lewis et al., 1993) and that of their habitats (Becker et al., 1985a,b, 1993a; Weseloh et al., 1990; Koster et al., 1996). In comparison with the published values of Herring Gull egg contamination, the eggs of Kelp Gulls in Chile showed much lower levels of most chemicals investigated, except for mercury (Table 3).

Various effects of chemical contaminants on the reproductive biology of birds are known (Ohlendorf et al., 1978; Scheuhammer, 1987; Nisbet, 1994; Fry, 1995), but direct relationships between pollutant levels and reproductive success are difficult to establish. Egg concentrations of mercury higher than $0.5 \mu \mathrm{g} \mathrm{g}^{-1}$ can have embryotoxic effects (Scheuhammer, 1987). We found lower mercury levels in the eggs of the Kelp Gull in Chile (Table 1). Also pp-DDE concentrations correlating negatively with eggshell thickness in Herring Gulls, were much higher $\left(2.8-9.5 \mu \mathrm{g} . \mathrm{g}^{-1}\right.$, Weseloh et al., 1990) than the values found in this study. PCB concentrations exceeding the range of 3 - $5 \mu \mathrm{g} \mathrm{g}^{-1}$ can cause embryotoxicity in birds (Lorenz and Neumeier, 1982, Common Tern Sterna hirundo, Linné 1758; Becker et al., 1993b). In general, the concentrations detected in this study are lower than levels known to cause biological effects in other gull species. None of the Kelp Gull eggs contained the extremely toxic non-orthoPCBs, and mono- and di-ortho-PCBs were found only in low concentrations, probably not producing negative effects on reproduction (e.g. Bosveld et al., 1995). 
To conclude, this first study of the geographical variation in chemical pollution of seabirds in Chile showed that the contamination of Kelp Gulls along the Chilean coast is very low, both by pesticides and by industrial chemicals, not at a level that would threaten the health of the species. To verify this we are expanding our project to other seabird species and to other chemicals, as those investigated represent only a small section of all compounds used in Chile. PCP (pentachlorophenol), for example, is broadly applied in forestry and produces environmental problems in some areas (Barra et al., 1995, Fossi et al., 1995).

\section{ACKNOWLEDGEMENTS}

We thank Susanne Mickstein, Pilar Martínez and Ursula Kirsig for taking egg samples, and Roberto Schlatter for manyfold support. Ute Sommer and K. R. Schmieder performed the chemicals analyses, Jacob González-Solís the Spanish summary. Chip Weseloh provided data on Herring Gull pollution from Ontario and gave helpful comments on the manuscript, as did also Silvano Focardi and Robert W. Furness. The study is part of a cooperation of the Institut für Vogelforschung, Wilhelmshaven, and the Instituto de Zoología, Universidad Austral de Chile, Valdivia, and was supported by the VolkswagenStiftung and the DAAD.

\section{REFERENCES}

Ballschmiter, K. and M. Zell. - 1980. Analyses of polychlorinated biphenyls (PCB) by glass capillary gas chromatography. Fresenius Z. Anal. Chem., 302: 20-31.

Barra, R., J.G. Rubin and M. Pérez. - 1995. Análisis comparativo del manejo y uso de los pesticidas en los Estados Unidos y Chile, pp. 1-90. Centro EULA, Chile. Universidad de Concepción.

Becker, P.H. - 1989. Seabirds as monitor organisms of contaminants along the German North Sea coast. Helgoländer Meeresunters., 43: 395-403.

Becker, P.H. - 1991. Population and contamination studies in coastal birds: The Common Tern Sterna hirundo. In: C.M. Perrins, J.D. Lebreton and G.J.M. Hirons (eds.): Bird population studies: Relevance to conservation and management, pp. 433460. Oxford University Press, Oxford.

Becker, P.H., A. Büthe and W. Heidmann. - 1985a. Schadstoffe in Gelegen von Brutvögeln der deutschen Nordseeküste. I. Chlororganische Verbindungen. J. Ornithol., 126: 29-51.

Becker, P.H., B. Conrad and H. Sperveslage. - 1989. Chlororganische Verbindungen und Schwermetalle in weiblichen Silbermöwen (Larus argentatus) und ihren Eiern mit bekannter Legefolge. Vogelwarte, 35: 1-10.

Becker, P.H., R.W. Furness and D. Henning. - 1993a. The value of chick feathers to assess spatial and interspecific variation in the mercury contamination of seabirds. Environ. Monitor. Assess., 28: 255-262.

Becker, P.H., W.A. Heidmann, A. Büthe, D. Frank and C. Koepff. - 1992. Umweltchemikalien in Eiern von Brutvögeln der deutschen Nordseeküste: Trends 1981-1990. J. Ornithol., 133: 109-124.

Becker, P.H., S. Schuhmann and C. Koepff. - 1993b. Hatching failure in Common Terns (Sterna hirundo) in relation to environmental chemicals. Environ. Pollut., 79: 207-213.

Becker, P.H., W. Ternes and H.A. Rüssel. - 1985b. Schadstoffe in Gelegen von Brutvögeln der deutschen Nordseeküste. II. Quecksilber. J. Ornithol., 126: 253-262.

Bosveld, A.T.C., J. Gradener, A.J. Murk, A. Brouwer, M. van Kampen, E.H.G. Evers and M. van den Berg. - 1995. Effects of PCDDs, PCDFs and PCBs in Common Tern (Sterna hirundo) breeding in estuarine and coastal colonies in the Netherlands and Belgium. Environ. Toxicol. Chem., 14: 99-115.

Bundesminister für Umwelt - 1988. Verordnung über Höchstmengen an Schadstoffen in Lebensmitteln (Schadstoff-Höchstmengenverordnung-SHmV). Bundesgesetzblatt, 1988: 422-424.

Drent, R.H. - 1970. Functional aspects of incubation in the Herring Gull. In: G.P. Baerends and R.H. Drent (eds.): The Herring Gull and its Egg. Behaviour, Suppl. 17: 1-132.

Focardi, S., C. Fossi, C. Leonzio, S. Corsolini and O. Parra. - 1996. Persistent organochlorine residues in fish and water birds from the Biobio River, Chile. Environ. Monitor. Assess., 43: 73-92.

Fossi, M.C., S. Focardi, C. Leonzio, R. Barra and O. Parra. - 1995. Use of biomarkers to evaluate effects of xenobiotic compounds in the Bío-Bío Basin (Central Chile). Environ. Contam. Toxicol., 55: 36-42.

Fry, D.M. - 1995. Reproductive effects in birds exposed to pesticides and industrial chemicals. Environ. Health Persp., 103: $165-171$.

Furness, R.W. - 1993. Birds as monitors of pollutants. In: R.W. Furness and J.J.D. Greenwood (eds.): Birds as monitors of environmental change, pp. 6-143. Chapman und Hall, London.

Henriksen, E.O., G.W. Gabrielsen and J.U. Skaare. - 1996. Levels and congener pattern of polychlorinated biphenyls in Kittiwakes (Rissa tridactyla), in relation to mobilization of body-lipids associated with reproduction. Environ. Pollut., 92: $27-37$.

Hoyo, J., A. Elliott and J. Sargatal. - 1996. Handbook of the birds of the world. Vol. 3. Lynx, Barcelona.

Koster, M.D., D.P. Ryckman, D.V.C. Weseloh and J. Struger. 1996. Mercury levels in great lakes Herring Gull (Larus argentatus) eggs. 1972-1992. Environ. Pollut., 93: 261-270.

Lewis, S.A., P.H. Becker and R.W. Furness. - 1993. Mercury levels in eggs, internal tissues and feathers of Herring Gulls Larus argentatus from the German Wadden Sea. Environ. Pollut., 80: 293-299.

Lorenz, H. and G. Neumeier. - 1982. Polychlorierte Biphenyle - ein gem. Bericht des BGA und UBA. MMV-Verlag, München.

Mattig, F.R., U. Ballin, H. Bietz, K. Gießing, R. Kruse and P.H. Becker. - 1997. Organochlorines and heavy metals in benthic invertebrates and fish from the back barrier of Spiekeroog. Arch. Fish. Mar. Res., 45: 113-133.

Nisbet, I.C.T. - 1994. Effects of pollution on marine birds. In: D. N. Nettleship, J. Burger and M. Gochfeld (eds.): Seabirds on Islands, pp. 8-25. Bird Life Conserv. Series No. 1.

Nisbet, I.C.T. and L.M. Reynolds. - 1984. Organochlorine residues in Common Terns and associated estuarine organisms, Massachusetts, USA, 1971-81. Mar. Environ. Res., 11: 33-66.

Ohlendorf, H.M., R.W. Risebrough and K. Vermeer. - 1978. Exposure of marine birds to environmental pollutants. Wildlife Res. Rep., 9, Washington, D.C.

Safe, S., S. Bandeira, T. Sawyer, L. Robertson, L. Safe, A. Parkinson, P.E. Thomas, D.E. Ryan, L.M. Reik, W. Levin, M.A. Denomme and T. Fujita. - 1985. PCBs: structure-function relationships and mechanism of action. Environ. Health Perspect., 60: 47-56.

Scheuhammer, A.M. - 1987. The chronic toxicity of aluminium, cadmium, mercury and lead in birds: a review. Environ. Pollut., 46: 263-295.

Seeler, R. - 1994. Chile mit Osterinsel. DuMont, Köln.

Sommer, U., K.R. Schmieder and P.H. Becker. - 1997. Untersuchung von Seevogeleiern auf chlorierte Pestizide, PCBs und Quecksilber. Bioforum, 20(3): 68-72.

Tillitt, D.E., G.T. Ankley, J.P. Giesy, J.P. Ludwig, H. Kurita-Matsuba, D.V. Weseloh, P.S. Ross, C.A. Bishop, L. Sileo and T.J. Kubiak. - 1992. Polychlorinated biphenyl residues and egg mortality in double-crested cormorants from the Great Lakes. Environm. Toxicol. Chem., 11: 1281-1288. 
Weseloh, D.V., P. Mineau and J. Struger. - 1990. Geographical distribution of contaminants and productivity measures of Herring
Gull in the Great Lakes: Lake Erie and connecting channels. Sci. Total Environ., 91: 141-159. 